\title{
Nilai Religi Arsitektur Rumah Adat Sasak Dusun Sade Desa Rembitan Kecamatan Pujut Kabupaten Lombok Tengah
}

\author{
Muaini' , Zainudin' \\ ${ }^{1}$ Pendidikan Sejarah, Universitas Muhammadiyah Mataram, muaini.awir@gmail.com \\ 2Pendidikan Agama Islam, STIT Darus Salimin, zen.murni@yahoo.co.id
}

\section{INFO ARTIKEL}

RiwayatArtikel:

Diterima: 23-11-2017

Disetujui: 25-12-2017

\section{Kata Kunci:}

1. Nilai Religi

2. Arsitektur Rumah Adat Sasak

\begin{abstract}
ABSTRAK
Penelitian ini bertujuan untuk mendeskripsikan makna nilai-nilai religi arsitektur rumah adat sasak. Jenis penelitian menggunakan kualitatif deskriptif. Penelitian dilakukan di dusun Sade desa Rembitan Kecamatan Pujut Kabupaten Lombok Tengah. Tehnik pengumpulan data mengunakan observasi, wawancara, dokumentasi dan catatan lapangan. Analisis data mengunakan kulitatif deskriptif. Hasil penelitian yang memiliki nilai-nilai religi arsitektur rumah adat sasak menemukan sebanyak 8 (delapan) yaitu: 1) Rumah Adat (Bale gunung rate ), 2) Arah rumah, 3) Bagian belakang rumah, 4) Atap rumah, 5) Lantai rumah, 6) Tangga rumah, 7) Pintu rumah, 8) Ruang dalam bale (Ruangan dalam). Masyarakat menjaga keaslihan peningalan kebudayaan dari nenek moyang.
\end{abstract}

This study aims to describe the meaning of religious values of traditional architecture of sasak house. This type of research uses descriptive qualitative. The research was conducted in Sade village of Rembitan village, Pujut Sub-district, Central Lombok Regency. Data collection techniques use observation, interview, documentation and field notes. Data analysis using descriptive skin. The result of research which have religious values of architecture of traditional house of sasak found as many as 8 (eight) that is: 1) Traditional house (Bale mount rate), 2) House direction, 3) Back of house, 4) Roof house, 5) , 6) Household staircase, 7) Door of house, 8) Space in bale (Room inside). Society keep the authenticity of cultural pengingalan from ancestors.

\section{A. LATAR BELAKANG}

Lombok merupakan pulau kecil yang dikenal dengan pulau seribu masjid yang memiliki keberanekaragam warisan budaya. Desa Rembitan merupakan salah satu desa di kecamatan Pujut kabupaten Lombok Tengah yang memiliki keunikan, bila dibandingkan dengan desa-desa lain. Desa tersebut terdapat satu dusun yang memiliki rumah adat tradisional di kenal dengan nama dusun Sade. Dusun Sade memiliki perkampunagan yang membangun khas rumah adat Sasak. Luas lahan yang disediakan untuk membangun rumah adat desa Rembitan sekitar satu hektar. Perkampungan rumah adat Sasak diperuntukkan bagi masyarakat dusun Sade yang ingin membangun rumah adat Sasak.

Kebudayaan masyarakat yang menarik untuk diperhatikan adalah arsitektur pembangunan rumah adat Sasak memiliki nilai-nilai religi disetiap bagian dari bangunannya. Masyarakat bekerja sama saling membantu membangun rumah adat secara ngotong royong, pemilik rumah berkewajiban mempersiapkan makan dan minum pada saat pembangunan rumah adat. Pembangunan rumah adat disesuaikan dengan wariga atau kelender tradisional. Nilai-nilai religi yang terkandung dalam arsitektur rumah adat dapat menjadi daya tarik bagi wisatawan untuk berkunjung ke perkampungannya tersebut.

Nilai-nilai religi yang terkandung dalam arsitektur perkampungan rumah adat dusun Sade begitu banyak, akan tetapi banyak masyarakat yang belum mengethui makna nilai-nilai yang terkandung di dalam arsitektur rumah adat Sasak. Oleh sebab itu perlu mengadakan penelitian Penelitian ini bertujuan untuk mendeskripsikan makna nilai-nilai religi arsitektur rumah adat sasak. 


\section{B. METODE PENELITIAN}

Jenis penelitian menggunakan kualitatif deskriptif. Penelitian dilakukan di dusun Sade desa Rembitan Kecamatan Pujut Kabupaten Lombok Tengah. Tehnik pengumpulan data mengunakan observasi, wawancara, dokumentasi dan catatan lapangan. Analisis data mengunakan kulitatif deskriptif.

\section{HASIL DAN PEMBAHASAN}

Suku Sasak adalah penduduk asli dan suku mayoritas di Lombok, Nusa Tenggara Barat sebagai penduduk asli, suku Sasak telah mempunyai sistem budaya sebagaimana terekam dalam kitab Nagara Kartha Gama karangan Empu Prapanca dari Majapahit. Dalam kitab tersebut, suku Sasak disebut "Lomboq Mirah Sak-Sak Adhi".Jika saat kitab tersebut dikarang suku Sasak telah mempunyai sistem budaya yang mapan, maka kemampuannya untuk tetap eksis sampai saat ini merupakan salah satu bukti bahwa suku sasak mampu menjaga dan melestarikan tradisinya. Salah satu bentuk dari bukti kebudayaan Sasak adalah bentuk bangunan rumah adatnya.

Rumah mempunyai posisi penting dalam kehidupan manusia, yaitu sebagai tempat individu dan keluarganya berlindung secara jasmani dan memenuhi kebutuhan spiritualnya. Memperhatikan bangunan rumah adat secara seksama, maka kita akan menemukan bahwa rumah adat dibangun berdasarkan nilai estetika dan kearifan lokal masyarakat, seperti halnya rumah tradisional suku Sasak dusun Sade di Lombok, Nusa Tenggara Barat. Rumah adat yang dingunakan sebagai tempat tinggal dan juga tempat penyelenggaraan ritual adat dan ritual keagamaan. Ada delapan nilai-nilai religi arsitektur yang terdapat di dalam rumah adat Sasak yaitu:

1. Rumah Adat (Bale gunung rate).

Bentuk rumah tradisional Lombok berkembang saat pemerintahan kerajaan Karang Asem (abad 17), dimana arsitektur Lombok dikawinkan dengan arsitektur Bali. Selain sebagai tempat berlindung, rumah juga memiliki nilai estetika, filosofi dan kehidupan sederhana para penduduk di masa lampau yang mengandalkan sumber daya alam sebagai tambang nafkah harian, sekaligus sebagai bahan pembangunan rumah. Pada dasarnya rumah adat Sasak sama dengan rumah pada umumnya, yang membedakannya dengan bangunan dari tempat lain adalah bangunan tersebut tidak berjendela. Lantai rumah juga terbuat dari campuran tanah liat dan kotoran kerbau. Semuanya memang ada artinya. Rumah tanpa jendela mengandung filosofi, manusia harus mensyukuri karunia yang dimilikinya dan tidak perlu menengok apa yang dimiliki orang lain.

2. Arah rumah

Bangunan rumah adat sasak mengarah ke arah timur dan barat yang menggambarkan kesepakatan dan persatuan yang terjalin di antara para penghuni rumah adat. Sebagaimana yang disampaikan Kurdap Selake rumah adat sasak Sade kulturnya dua arah menghadap ke Barat dan Timur (bahasa Sasak : penewok jelo dan peyerap jelo) maknanya adalah rumah yang mengadap ke timur menggambarkan kita sebagai manusia terlahir di dunia untuk bekerja dan berjuang mencari bekal (sango) menuju akherat. Adapun rumah yang menghadap ke barat menggambarkan bahwa hidup didunia ada akhirya yaitu "kematian" meninggalkan dunia.

Selain itu yang menarik untuk di perhatikan dari rumah adat sasak yang ada di dusun Sade adalah pola pembangunannya. Apabila ada rumah adat yang menghadap arah lain maka tokoh adat dan mayarakat berhak merusak bangunan secara paksa karna membangun tidak sesaui dengan kesepakatan peninggalan dari nenek moyang. Sebagaimana yang dijelaskan Kurdap Selake, sebagai berikut :

"laek lamuna arak dengan minak bebale ampokn nak andang lain kanggo iteenjaet ye bareng batur, aranjek papuk balokt nyuruk ite minak bale andang timuk dait bat doang dekne kanggo andang lain. Mune andang lain tparanite dekn mele nurut lek batur luek ya apoknite kanggo nyarakn".

Pada zaman dulu kalau ada orang yang mau membuat rumah terus menghdap ke arah lain maka rumah-rumahan itu boleh di rusak oleh tokoh adat dan masyarakat, karna nenek moyang kita menyuruh kita menghadap timur dan barat tidak boleh ke arah lain. Kalau rumah itu menghadap arah lain maka kita di katakan tidak mengikuti masyarakat maka dari itu boleh di rusak.

Proses pembangunan rumah adat ini dilakukan secara gotong royong dan kekeluargaan tanpa adanya 
upah dan bayaran bagi setiap orang yang ikut membantu membangun rumah adat tersebut. Pemilik rumah atau orang yang akan membangun rumah hanya menyiapkan bahan-bahan yang di perlukan dalam proses pebangunan rumah adat itu sendiri seperti mempersiapkan kayu, bambu, pager, ilalang, getah pohon banten, getah pohon bajur, jerami, daun tapen dan lain-lain yang diperlukan untuk keperluan membangun rumah.

3. Bagian belakang rumah

Masyarakat sasak Sade, menggap rumah dalam dimensi yang sakral (suci) dan profan duniawi secara bersamaan. Makna rumah adat Sasak disamping sebagai tempat berlindung dan berkumpulnya anggota keluarga juga menjadi tempat dilaksanakannya ritual-ritual sakral yang merupakan manifestasi dari keyakinan kepada Tuhan, arwah papuk balok bale (nenek moyang penunggu rumah), dan sebagainya. Sebagaimana yang disampaikan oleh Kurdap Selake :

"papuk balok sakelek laek sampe nani sanget sikne percaye le hal-hal sik gaib, marak misal sadu le kekuatan jampi-jampian, seher, atao roh-roh papuk balok si wah bejulu bilin ite. Meretoh juak marakwaktun sak penganjeng bale. Endekn ne selapuk waktu bau dait bagus taokminak bale. Arak waktu si bagus taok te minak bale dait endah arak waktu si endekn bagus taokt minak bale. Lamun ta minak bale le waktu si endekn bagus pasti endek nak lancar-lancar pegaweant nike, lamun wah jari pasti endah bale nikeji sial-sial dirikn. Pokokne arak doang bin dait. Waktu si bagus taokte minak bale niki bulan ke telu dait bulan sik ke due olas mun penanggalan sasak mun kalender islam jek pade kenen dait bulan rabiul awal dait bulan zulhijjah. Lamun bulan sik tokte endekn kanggo minak bale nike jek bulan muharam dait bulan ramadan.

Nenek moyang kita dari dulu sampai sekarang sangat percaya dengan hal-hal yang gaib, seperti percaya pada jampi-jampi, sihir atau arwah nenek moyang yang sudah meninggalkan kita terlebih dahulu. Begitu juga dengan waktu kita mendirikan rumah. Tidak semua waktu bagus untuk mendirikan rumah. Ada waktu yang baik untuk mendirikan rumah dan ada juga waktu yang kurang baik untuk mendirikan rumah. Kalau kita mendirikan rumah pada waktu yang kurang baik maka dalam proses pembangunan rumah itu tidak akan lancar, ada saja sesuatu yang kurang dan ada juga kendala-kendalanya. Apabila rumah itu sudah jadi maka rumah itu akan selalu mendapat kesialan, waktu yang baik untuk mendirikan rumah adalah pada bulan ke tiga dan bulan ke dua belas penanggalan sasak yang bertepatan dengan bulan rabiul awal dan bulan zulhijjah. Kalau bulan yang kurang baik untuk membangun rumah adalah bulan muharam dan bulan ramadan.

Masyarakat dusun Sade meyakini bahwa waktu yang baik untuk memulai membangun rumah adalah pada bulan ke tiga dan bulan kedua belas penanggalan sasak, yaitu bulan rabiul awal dan bulan Zulhijjah pada kalender Islam. Ada juga yang menentukan hari baik berdasarkan nama orang yang akan membangun rumah. Sedangkan bulan yang paling dihindari (pantangan) untuk membangun rumah adalah pada bulan Muharam dan Ramadan. Pada kedua bulan ini, menurut kepercayaan masyarakat setempat, rumah yang dibangun cenderung mengundang malapetaka, seperti penyakit, kebakaran, sulit rizki dan sebagainya.

\section{Atap rumah}

Bahan untuk membuat atap rumah antara lain: kayu penyangga, bambu, anyaman dari bambu untuk dinding dan ilalang. Rumah adat Sasak Sade yang dominan berukuran sekitar 7 x 5 meter dan pada atapnya berbentuk gunung, menukik kebawah dengan jarak sekitar 1,5-2 meter dari permukaan tanah (pondasi).

Salah satu bentuk dari bukti eksistensi kebudayaan suku sasak adalah bentuk bangunan rumah adatnya. Rumah bukan sekedar tempat hunian yang multi fungsi, melainkan juga mempunyai nilai estetika dan pesan-pesan filosofi bagi penghuninya, baik arsitektur maupun tata ruangnya. Atap dan bubunganya (bungus) terbuat dari ilalang (re), dindingnya terbuat dari anyaman bambu. Semua rumah adat yang ada di dusun Sade dinamakan Bale Gunung Rate merupakan gabungan bentuk gunung dan rate.

Filosofi religius: Sebagai alam mikro/makrokosmos dimana rumah itu dijadikan sebagai aktifitas kerumah tanggaan. Atap rumah, gunung menunjukkan keagungan-alam ketuhanan/besar sedangkan Rate eksistensi manusia sebagai mahluk yang lemah dan memiliki kesamaan derajat atau drajat yang sama dihadapan Tuhan Yang Maha Kuasa.

5. Lantai rumah. 
Lantai rumah dibuat dari campuran dari tanah, getah pohon kayu banten dan bajur (istilah lokal), batu bata yang ada dalam batu baterai, dan abu jerami yang dibakar, kemudian diolesi dengan kotoran kerbau atau kuda dibagian permukaan lantai. Materi membuat lantai rumah ini berfungsi sebagai zat perekat, selain itu juga berfungsi untuk menghindari lantai menjadi lembab. Bagian rumah yang menggunakan lantai yaitu bagian luar (sesangkok luar) dan bagian dalem rumah (bale dalem dan dalem bale).

Secara spesifik bangunan Bale Gunung Rate terdiri dari beberapa bagian ruang yaitu; Langan Dalem(bagian dalam), terdiri dari Dalem bale tempat tidur dan memasak dan Bale Dalem tempat melahirkan. Langan Duah (bagian luar), terdiri dari; Sesangkok kawan; tempat menerima tamu dan Sesangkok kiri; tempat untuk kaum ibu. Ruangannya dibagi menjadi bale luar dan bale dalem. Bale luar disebut sesangkok yang berfungsi sebagai tempat menerima tamu.

Secara geografis bahwa daerah Lombok bagian selatan pada umumnya memiliki konstruksi tanah hitam yang mudah retak pada musim panas. Sehubungan dengan itu, maka untuk mengepel lantai menggunakan kotoran sapi atau kerbau dan diperhalus dengan batu agar mengurangi retak pada lantai. Lantai yang dipel dengan kotoran sapi atau kerbau menurut kepercayaan masyarakat merupakan apresiasi terhadap hewan ternak atau penghormatan terhadap hewan korban, baik sebagai hakikah, khitanan dan lain-lain. Dan mengandung pesan, manusia harus mampu bekerja keras tanpa banyak mengeluh.

\section{Tangga rumah}

Konstruksi rumah tradisional Sasak terkait pula dengan persefektif agama Islam. Anak tangga sebanyak tiga tingkat adalah simbol daur hidup manusia: lahir, berkembang dan mati sedangkan anak tangga yang berjumlah lima tingkat melambangkan rukun islam yang lima yaitu (membaca syahadat, shalat lima waktu sehari semalam, puasa pada bulan ramadan, membayar zakat dan naik haji bila mampu). Hal itu diungkapkan oleh Kurdap Selake bahwa :

"papuq balok te si laek-laek minak bale endekn ne semate-mate jari taokte tindok doang, laguk aden te inik gamakn sik tetep-tetep inget le epenth sak minak ite. Maraktan undak-undak sak telu atau lima nike. Endekn semate-mate minak undak-undak isiknnaktekadu liwat-liwat doang laguk munte liwat harus endah ite tetep inget lek epente. Undak-undak sik telu nike artin manusie setohteperanakang, terus berombok terus mate. Lamun undak-undak sak lime nike jekn artin rukun islam sak wajib ite taokn arak lime, bace due kalimah sahadat, sembayang lime waktu, puase wajib lek bulan ramadan, nyugulang jekat dait taek haji munt pade mampu".

Nnenek moyang kita yang membuat rumah tidak semata-mata membuat rumah hanya menjadi tepat tinggal atau hunian saja melainkan rumah adat dibangun sebagai tempat untuk mengingat sang pencipta yang menciptakan kita (manusia). Seperti pembuatan anak tangga yang tiga atau lima. Pembuatan anak tangga tidak semata-mata sebagai alat yang di pakai untuk lewat-lewat saja tetapi apabila kita lewat kita harus ingat dengan diri kita dan ingat Tuhan yang menciptakan kita. Anak tangga yang tiga artinya manusia itu di lahirkan, berkembang dan selanjutnya meninggal dunia. Sedangkan anak tangga yang lima buah mengingatkan kita pada rukun islam yang lima yaitu (membaca syahadat, shalat lima waktu sehari semalam, puasa pada bulan ramadan, membayar zakat dan naik haji bila mampu)".

\section{Pintu rumah}

Bale gunung rate mempunyai tiga pintu (lawang) yakni Lawang angkok (pintu luar), lawang dalem bale dan lawang bale dalem yang memiliki ukuran $125 \mathrm{~cm}$, panjang sekitar $70 \mathrm{~cm}$ dan lebar $10 \mathrm{~cm}$. Bentuk lawang bale gunung rate adalah berbentuk lawang pelung. Lawang pelung adalah pintu yang menghubungkan antara bale luar dan bale dalem yang berbentuk bundar dan memiliki dua pegangan untuk membuka dan menutup pintu dengan cara didorong dan ditarik ke kanan dan ke kiri.

Ukuran pintu yang rendah tersebut dimaksudkan bahwa setiap keluar masuk rumah bagi pemilik rumah sebagai ungkapan rasa syukur kepada sang pencipta, sedangkan bagi tamu, sebagai ungkapan salam dan hormat terhadap pemilik rumah. Bangunan rumah adat ini juga memiliki 3 pintu yang pendek atau rendah. Makna yang terkadung dari pintu yang rendah adalah tamu yang masuk harus menghormati pemilik rumah dengan cara menundukkan kepalanya. 
"laek le mase si deknman naon salam dengan lamun nak tame lek balen dengan lain pasti na ngucap tabe walar salokne nunduk atau bongkok sekedik".

Pada zaman dulu di masa orang belum tahu salam, kalau mau masuk ke rumah orang harus mengucapkan permisi sambil menundukkan kepala dan membungkukkan badan sedikit.

8. Ruangan dalem bale (Ruangan dalam)

Ruangan baledalem (ruangan bagian dalam) dibagi lagi menjadi dua ruangan yaitu ruangan tempat tidur, ruangan persemayaman janazah dan, tempat melahirkan. Karena ruangan tempat persemayaman janazah dan ibu melahirkan tidak dipakai tiap hari maka untuk sementara waktu ruangan dipakai untuk menyimpan harta benda dan alat-alat pertanian.

Ruangan Baledalem dilengkapi dengan amben, dapur dan sempare (tempat menyimpan makanan dan peralatan rumah tangga lainnya) terbuat dari bambu dengan ukuran $2 \times 2$ meter persegi atau bisa empat persegi panjang. Fungsi ruangan bale dalem atau ruang sakal yaitu tempat melahirkan, tempat sejata-senjata tradisional, tempat beras, dan tempat tafakur/berkhaluwat. Pungsi dalem bale adalah sebagai tempat tidur bagi kaum perempuan. Selain itu ada sesangkok (ruang tamu) dan pintu masuk dengan sistem geser. Di antara bale luar dan bale dalem ada pintu dan tangga (tiga atau lima anak tangga) dan lantainya berupa campuran tanah dengan kotoran kerbau atau kuda, getah dan abu jerami. Undakundak (tangga), digunakan sebagai penghubung antara bele luar dan bale dalem.

\section{SIMPULAN DAN SARAN}

Masyarakat dusun Sade masih memegang teguh keyakinan bahwa rumah mempunyai posisi penting dan berada dalam dimensi sakral (suci) dan duniawi secara bersamaan. Rumah sebagai tempat berlindung dan berkumpulnya anggota keluarga juga menjadi tempat dilaksanakannya ritual-ritual sakral yang merupakan manifestasi dari keyakinan kepada tuhan dan arwah nenek moyangnya. Masyarakat menjaga dan melestarikan nilainilai religi arsitektur yang terkandung dalam rumah adat sasak.

\section{DAFTAR RUJUKAN}

Adonis, Tito. Ed. Suku Terasing Sasak. Jakarta: PT. Inter Masa. Bungin, Burhan.2008. Penelitian Kualitatif;Komunikasi, Ekonomi, Kebijkakan Publik, Ilmu Sosial Lainnya. Jakarta: Kencana Prenada Media Grup.

Cholid, Achmadi. 2004. Metodologi penelitian Sosial. Jakarta: PT. Bumi Aksara.

Kuntara. 2002. Semiotika Budaya. Bandung: PT Rosdakarya.

Kurdap Selake. 2011. Mengenal Budaya Dan Adat Komunitas Suku Sasak Di Dusun Tradisional Sade. Mataram: Dinas Kebudayaan Dan Pariwisata Prov. NTB.

Masinambow. 1997.Koentjaraningrat dan Antropologi di Indonesia. Jakarta: Yayasan Obor Indonesia.

Melalatoa, Junus, M. 1985.Ensiklopedi Suku Bangsa Di Indonesia Jilid A-K. Jakarta: CV. Ekaputra.

Moleong, Lexy J. 2010. Metodologi Penelitian Kualitatif Edisi Revisi. Bandung: PT. Remaja Rostakarya.

Nazir.1998. Metode Penelitian Naturalistik Kualitatif. Bandung:Trarsito

Redaksi Ensiklopedia Indonesia. 1990.Ensiklopedia Indonesia Seri Geografi. Jakarta: PT Ichtiah Baru Vanhoeve, dicetak oleh Jakarta: PT. Inter Masa

Setiadi, et al.2008. Ilmu Sosial dan Budaya Dasar. Jakarta: Kencana Perdana Media Group.

Sobur, Alex. 2006. Semiotika Komunikasi. Bandung: PT Reramaja Rosdakarya.

Sugiyono.2009. Metodologi Penelitian Kuantitatif Kualitatif Dan $R \& D$. Bandung: Alfabeta.

Wacana,Lalu.197.MonografiDaerah Nusa TenggaraBarat. Mataram:Departemen Pendidikan dan Kebudayaan.

Wacana,Lalu.1985.Sejarah Nusa Tenggara Barat. Jakarta:Departemen Pendidikan Dan Kebudayaan.

Wahyu. 2008.Ilmu Budaya Dasar.Bandung: Pustaka Setia.

Zaelani, Kamarudin. 2007.Teologi Wetu Telu: Melacak Akarb sejarah TerbentuknyaTeologi Wetu Telu. Mataram : PT. Pantheon Presindo.

http://jaurilmu,wordpres/2009/09.Bangunandanarsitektur.html.com.diakses pada 26 juli 2017, jam 14.20 